\title{
A COMPARISON OF CHORIONIC SCULPTURING OF FOUR INDIAN PHLEBOTOMINE SANDFLIES (Diptera: Psychodidae) by sCANNINg eleCtron microscopy
}

\author{
GHOSH K.N.** \& MUKHOPADHYAY J.**
}

\section{Summary:}

The chorionic sculpturing of four Indian sandfly species: Phlebotomus argentipes Annandale \& Brunetti, P. papatasi (Scopoli), P. major major Annandale and Sergentomyia zeylanica (Annandale) was investigated with the help of scanning electron microscopy. It was found that $P$. argentipes and $P$. papatasi show similar type of chorionic sculpturing i.e., parallel connected ridges and ridge column palisade consisting of several small granules spaced in a double series, arranged longitudinally. However, morphology of each ridge is very different, particularly near the two ends of the egg and also where there is a formation of hexagonal areas. The interridge area and basal layer of $P$. papatasi egg show multiple granular elevation which look like multiple minute microvilli like projections whereas in case of $P$. argentipes, there is reticular structure formation by fibrous material. In P. m. major and $S$. zeylanica, the egg surface pattern is found to be polygonal but in case of $S$. zeylanica almost all the polygons are of equal sizes and each ridge consists of flattened cells of different sizes arranged in a palisade. On the other hand, in P. m. major, there is no uniformity on the size and shape of the polygons and they look like that the ridges are formed by the fusion of the flattened cells. These species specific characters will be useful in identifying different sandfly species on the basis of their chorionic sculpturing pattern and consequently it will help to indicate the relatedness of sandfly species i.e., sandfly taxonomy.

KEY WORDS : sandflies, Phlebotomus argentipes, P. papatasi, P. m. major, Sergentomyia zeylanica, eggs, chorionic sculpturing, SEM.

MOTS CLÉS : phlébotomes, Phlebotomus argentipes, P. papatasi, P.m. major, Sergentomyia zeylanica, œufs, ornementation chorionique, SEM.
Résumé : COMPARAISON PAR MICROSCOPIE ÉLECTRONIQUe À BALAYAGE DES ORNEMENTATIONS CHORIONIQUES DE QUATRE ESPĖCES INDIENNES DE PHLÉBOTOMES (DiPTERA: PSYCHODIDAE)

Les ornementations chorioniques de quatre espèces indiennes de phlébotomes (Phlebotomus argentipes Annandale et Brunetti, P. papatasi (Scopoli), P. major major Annandale et Sergentomyia zeylanica Annandale) sont décrites par analyse en microscopie électronique à balayage. P. argentipes et $P$. papatasi possèdent des ornementations chorioniques similaires, telles que les rainures parallèles connectées et les rainures en colonnes palisadées formées de plusieurs petits granules espacés en séries doubles et orientés longitudinalement. Cependant, la morphologie de chaque rainure diffère, en particulier aux deux extrémités de l'œuf ainsi qu'au niveau des zones de formation des aires hexagonales. La région entre les rainures ainsi que la couche basale des œufs de P. papatasi se caractérisent par de multiples protubérances granuleuses ressemblant à des projections microvillositaires multiples. Chez P. argentipes, cette zone se présente sous forme d'une formation réticulaire constituée de matériel fibreux. Le motif de surface des œuts de P. m. major et S. zeylanica est polygonale. Quant à celui de S. zeylanica, la quasi totalité des polygones sont de taille égale et chaque rainure est formée de cellules aplaties de différentes tailles organisées en palisade. Par contre, chez P. m. major, il n'y a aucune uniformité de taille et de forme des polygones et il semblerait que les rainures sont issues de la fusion de cellules aplaties. La spécificité des motifs chorioniques s'avère être un bon critère d'identification des différentes espèces de phlebotomes et devrait en conséquence être utile à définir plus clairement la position taxonomique des diverses espèces de phlébotomes.
Department of Zoology, University of Calcutta, 35 Ballygunge Circular Road, Calcutta 700 019, India.

* Present address: Yale Arbovirus Research Unit, Department of Epidemiology and Public Health, School of Medicine, 60 College street, PO Box 208034, New Haven, Connecticut 06520-8034, USA.

Correspondence: K.N. Ghosh.

\section{INTRODUCTION}

F ollicular development of sandflies like other haematophagous insects is dependent on blood meal. However, some of the them have been reported to be autogenous in nature (Johnson, 1961; Killick-Kendrick, 1987). The time of egg laying varies in different insects and each egg reflects characteristics of the species, both biochemically and morphologically. Probably, it is impossible to differentiate the 
very tiny eggs of the closely related species with some morphological parameters. Therefore, attempts have been made to differentiate eggs of related species by analysing the exochorion of the laid eggs. The structure of the exochorion reflects the shape of the follicular cells in the ovariole and thus, they are the manifestation of a character of the adult. To an even larger extent, the same thing is true for the tertiary egg shells, which are formed by secretions of the female genitalia in combination with action based on inherited instincts of the adult (Emden, 1957). This egg shell protects the developing embryo from the external environment. It also helps in gaseous exchange and prevents dessication and thereby help in the proper development of the embryo.

Studying egg surface of the phlebotomine sandflies had been initiated long ago with light microscopy of $P$. argentipes (Howlett, 1909). Later, similar attempts have been continued to study the New World sandfly eggs (Linguist, 1936; Barretto, 1941; Addis, 1945; Sherlock 1957; Sherlock \& Caneiro, 1963; Chaniotis \& Anderson, 1964) and also the Old World sandfly eggs (Saccà, 1950, 1952; Perfil'ev, 1966; Abonnenc, 1972; Trouillet, 1977, 1979). However, most of the authors faced difficulty in separating the eggs of the closely related species with light microscopy.

Scanning Electron Microscopy (SEM) has been introduced later to see the finer structure of the chorionic sculpturing of insect eggs with the help of its three dimensional view. Initially more work has been done with SEM of mosquito eggs (Hinton, 1968, Hinton \& Service, 1969, Matsuo et al., 1974) and later Ward \&
Ready (1975) first introduced SEM to see the outer chorionic sculpturing of 13 species of New World sandflies from Brazil. Other workers (Zimmerman et al., 1977; Endris et al., 1987 \& Feliciangeli et al., 1993) continued similar study on other species of New World sandflies and contributed altogether egg sculpturing of 49 species. On the other hand, very little attempt has been made with the Old World sandflies. Of the ten species so far described, Irungu et al. (1986), Lane \& El-Sawaf (1987), Gebre-Michael \& Lane (1991) \& Fausto et al. (1992) have explored the egg sculpturing pattern of four, one, two and three species respectively (Table I). Their observations clearly indicate that the Old World sandflies are less studied. Here, we report the chorionic sculpturing of four Indian phlebotomine sandflies with the help of SEM.

\section{MATERIALS AND METHODS}

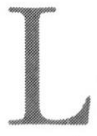
aboratory colonies of Phlebotomus argentipes Annandale \& Brunetti and P. papatasi (Scopoli) were maintained following the method of Ghosh et al. (1991). The eggs of the two species were taken from the respective colonies. Females of P. m. major Annandale and $S$. zeylanica (Annandale) were collected from Dankuni and Salt Lake area of West Bengal respectively. The eggs were collected by feeding the wild caught females on house lizard in the laboratory following the method of Ghosh \& Bhattacharya (1989). The species were identified by the keys provided by Theodor (1938) as modified by Lewis (1978).

\begin{tabular}{|c|c|c|c|c|c|c|c|}
\hline \multirow{2}{*}{ Species } & \multirow{2}{*}{ Origin } & \multicolumn{5}{|c|}{ Pattern } & \multirow{2}{*}{ Reference } \\
\hline & & $\mathrm{P}$ & $\mathrm{PR}(\mathrm{C})$ & PR(UC) & Vol & Network & \\
\hline$P$. argentipes & India & & $\begin{array}{l}\mathrm{X} \\
\mathrm{X}\end{array}$ & & & & $\begin{array}{l}\text { Ghosh \& Bhattacharya, } 1993 \\
\text { This paper }\end{array}$ \\
\hline P. celiae & Ethiopia & & & & & $\mathrm{X}$ & Gebre-Michael \& Lane, 1991 \\
\hline P. duboscqi & Kenya & & & & & $\mathrm{X}$ & Fausto et al., 1992 \\
\hline P. langeroni & Egypt & & & $\mathrm{X}$ & & & Lane \& El-Sawaf, 1986 \\
\hline \multirow[t]{2}{*}{ P. martini } & Kenya & & & $\mathrm{X}$ & & & Irungu et al., 1986 \\
\hline & Ethiopia & & & & & $\mathrm{X}$ & Gebre-Michael \& Lane, 1991 \\
\hline P. major & India & $\mathrm{X}$ & & & & & This paper \\
\hline \multirow[t]{3}{*}{ P. papatasi } & Italy & & $\mathrm{X}$ & & & & Fausto et al., 1991 \\
\hline & Italy & & $\mathrm{X}$ & & & & Fausto et al., 1992 \\
\hline & India & & $\mathrm{X}$ & & & & This paper \\
\hline P. perfiliewi & Italy & & & $\mathrm{X}$ & & & Fausto et al., 1992 \\
\hline P. perniciosus & Italy & & $\mathrm{X}$ & & & & Fausto et al., 1992 \\
\hline S. bedfordi & Kenya & $\mathrm{X}$ & & & & & Irungu et al., 1980 \\
\hline S. garnhami & Kenya & & & $\mathrm{X}$ & & & Irungu et al., 1980 \\
\hline S. kirki & Kenya & & & & $\mathrm{X}$ & & Irungu et al., 1980 \\
\hline S. zeylanica & India & $\mathrm{X}$ & & & & & This paper \\
\hline
\end{tabular}

Table I. - Chorionic sculpturing of Old World sandflies as observed by SEM.

P: polygonal, PR(C): parallel ridge (connected), PR(UC): parallel ridge (unconnected), Vol: volcanic and Network (synonymous to reticular). 
For SEM examination, the laid eggs were allowed to embryonate for 2-3 days. Then, the eggs were collected with the help of a fine brush and washed with PBS to clear the egg surface. Then, they were fixed in $1 \%$ gluteraldehyde solution in cold for 2-3 hrs. The solution was replaced by $3 \%$ gluteraldehyde and left overnight at $4^{\circ} \mathrm{C}$. On the following day, the eggs were washed with PBS ( $\mathrm{pH}$ 7.2) to remove excess gluteraldehyde from the samples and subsequently passed through upward grades of ethanol keeping 10-15 min in each grade. Lastly, absolute ethanol was replaced by isoamyl acetate. The samples were then dried in a critical point drying apparatus (Polaron E500) and mounted on a metal stub with the help of double sided adhesive tape. The eggs were then coated with an alloy of $\mathrm{Au}-\mathrm{Pd}$ of $200-300 \mathrm{~A}^{\circ}$ thickness in a sputter coater (Edwards S150). The coated samples were viewed and photographed under a Philips SEM (PSEM 500) at varying beam of current, tilt angles.
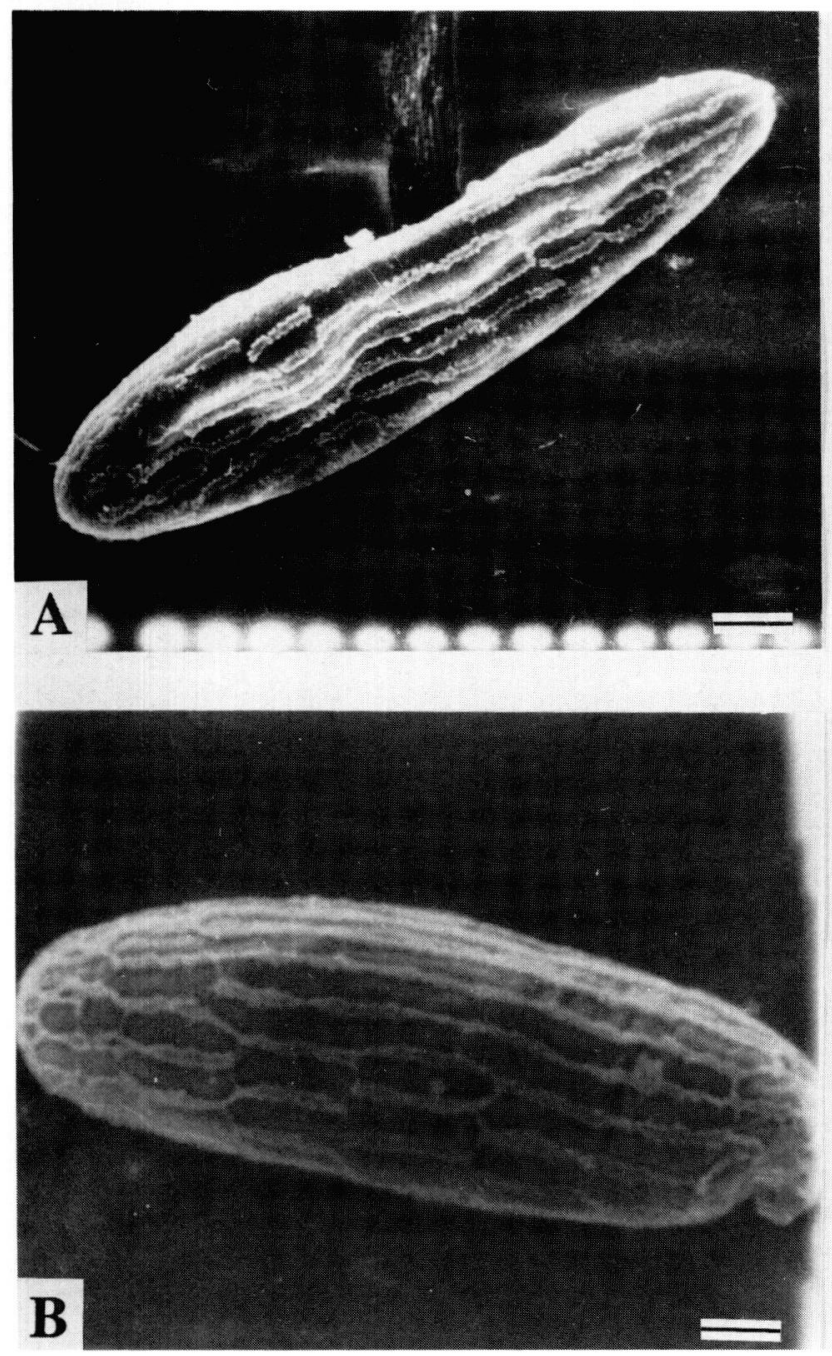

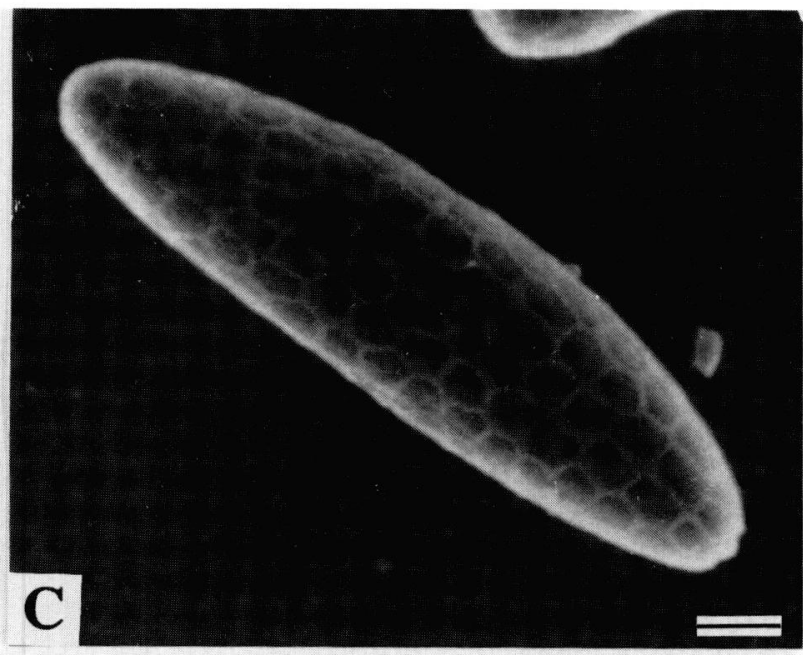

\section{RESULTS}

1 igs. 1-3 indicate the ultrastructure of exochorion of the eggs of the following four Indian phlebotomines.

\section{P. ARGENTIPES}

Egg length $320 \mu \mathrm{m}$; breadth (middle) $72 \mu \mathrm{m}$. The eggs are almost spindle shaped with one end of the spindle broader than the other. The basic pattern of chorionic sculpturing shows parallel interconnecting ridges. In some areas, the bifurcating branches of the adjacent parallel longitudinal ridges unite one another encroaching few hexagonal structures (Fig. 2A). These branches act as interconnecting ridges which are very short in length. Closer observation reveals that each parallel ridge is actually composed of two very close rows of small granular protuberances with intermediate

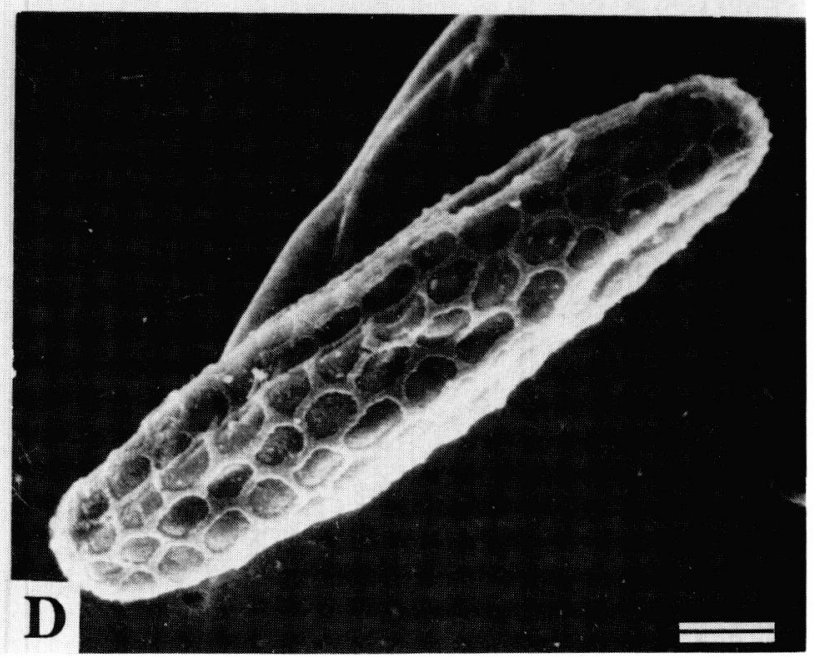

Fig. 1. - SEM micrographs showing the characteristics ridge pattern of the outer chorionic sculpturing of four Indian sandfly eggs. P. argentipes (A); P. papatasi (B); P. m. major (C); S. zeylanica (D). (Bar $=30 \mu \mathrm{m})$. 
spaces. The individual granules of the two rows are alternately arranged. At even higher magnification, each granule appears to be triangular in shape with central elevation. The basal egg surface (inter-ridge areas) is actually a rough area having intercalated networks which extend up to the base of the granules of the ridges (Fig. 3A).

\section{P. PAPATASI}

Egg length $317 \mu \mathrm{m}$; breadth (middle) $106 \mu \mathrm{m}$. The two ends of the eggs are almost blunt, thus giving a thick, short, rod shaped appearance. Here, the basic pattern of chorionic sculpturing is also parallel interconnected ridges but the longitudinal ridges are not always uni-
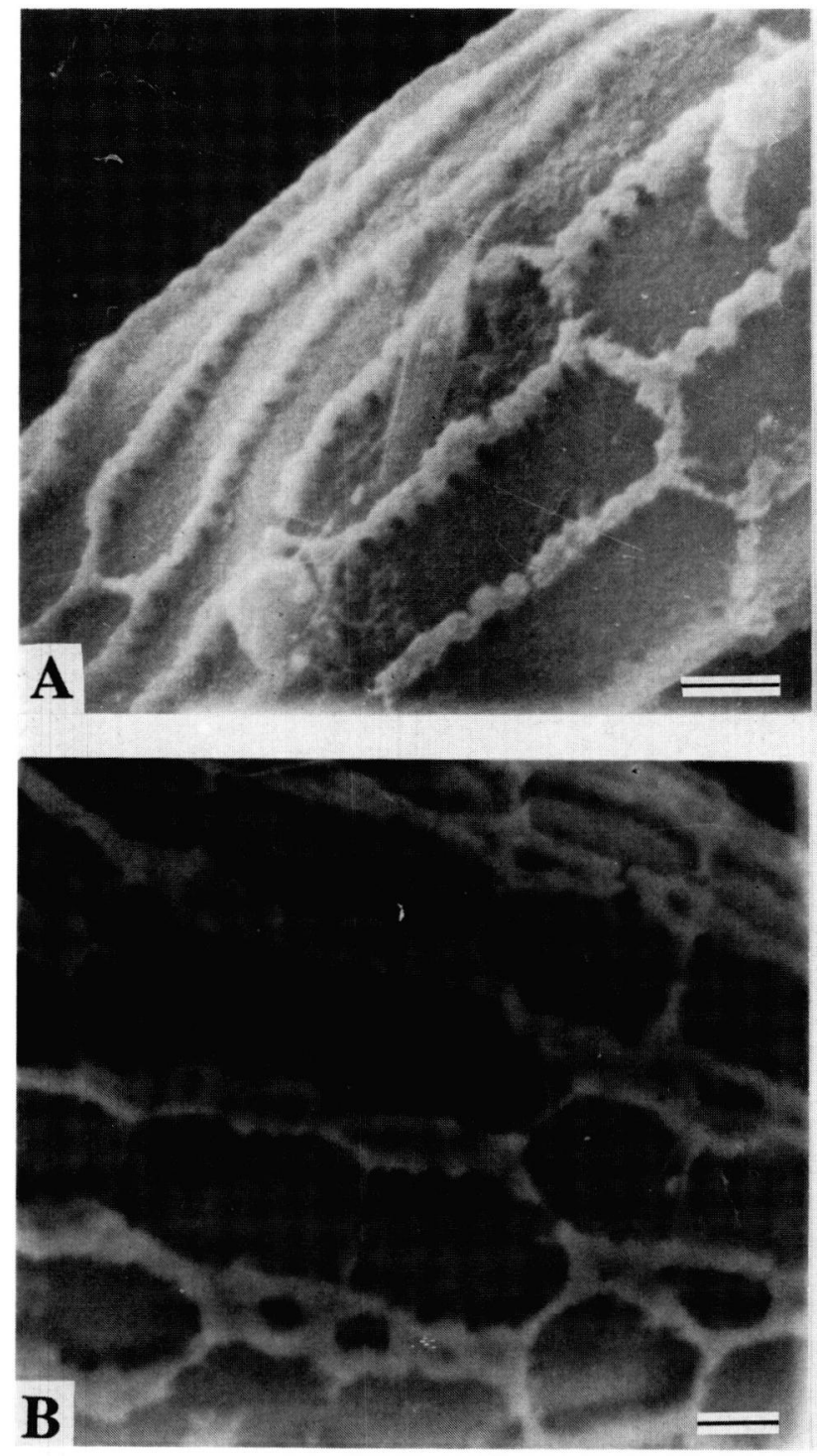

form. In areas, where the ridges are thicker, particularly closer to the two ends, they form quadrangular gaps of different sizes (Fig. 2B). It may be the fact that the ridges are actually composed of two individual rows which in some areas have fused and in other areas exist separately thereby encroaching an area in between the two rows. The pattern of distribution of ridges nearer the ends of the egg shows network like structure which is formed by the branching of the longitudinal ridges (Fig. 2B). The interconnecting ridges are thinner in comparison to the longitudinal ridges and looks like a very small side branch of the longitudinal ridges (Fig. 2B). The basal egg surface (interridge areas) is rough, having uniform small granular protuberances which look like multiple microvilli.
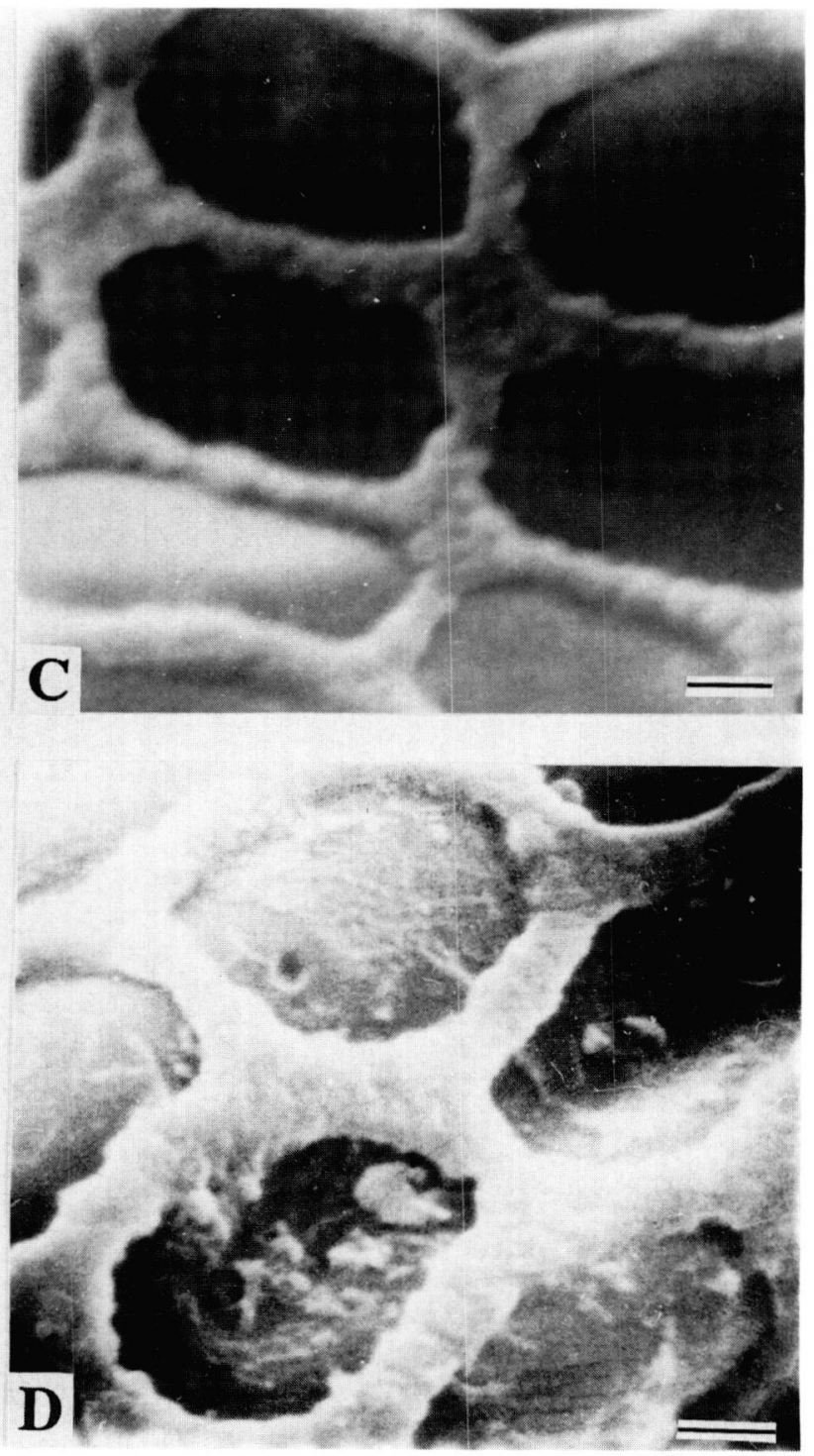

Fig. 2. - SEM micrographs of the selected region of egg surface of the four sandflies showing ridge arrangement, interconnection and polygon formation.

P. argentipes $(\mathrm{A}) ;$ P. papatasi $(\mathrm{B})($ Bar $=8 \mu \mathrm{m}) . P . m$. major $(\mathrm{C}) ;$ S. zeylanica $(\mathrm{D})($ Bar $=4 \mu \mathrm{m})$. 


\section{P. M. MAJOR}

Egg length $200 \mu \mathrm{m}$ and breadth (middle) $74 \mu \mathrm{m}$. Eggs are spindle shaped with polygonal structures on their surface area. The pattern of polygon formation is not uniform having quadrangles, pentagons or hexagons (Fig. 1C). Each ridge of the chorion consists of columns of granular cells arranged to form a palisade. In some areas, the ridge shows single row of quadrangular granular cells whereas in other areas, as in the corners, there is no separate existence of individual cells and the cells appear to be fused and the ridges are also wider (Fig. 2C). At higher magnification, the ridge surface shows multiple small depressions which makes the surface rough (Fig. 3C).

\section{S. ZEYLANICA}

Egg length $266 \mu \mathrm{m}$ and breadth (middle) $64 \mu \mathrm{m}$. Each egg is a narrow, rod like structure having two blunt ends

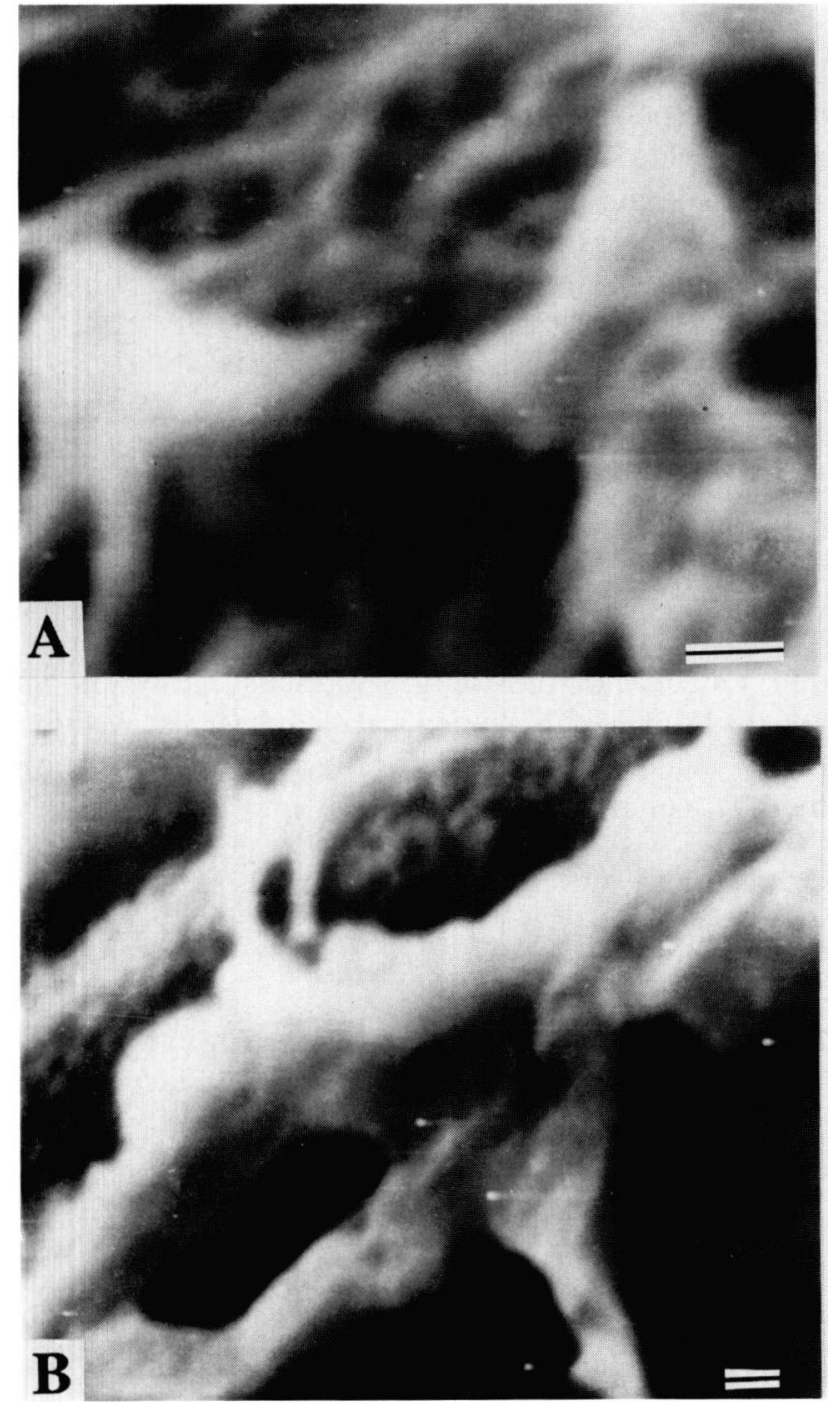

(Fig. 1D). Here, the egg surface consists of symmetrical hexagons which are uniformly distributed throughout the egg surface (Fig. 1D). In lower magnification, the ridges appear to be wide and solid, uniform cord like structures. However, at higher magnification, the surface of the ridge shows unevenness with the existence of different solid granules of various sizes, arranged in a column to form a palisade (Fig. 3D).

\section{DISCUSSION}

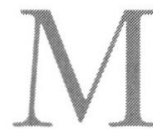
orphological characters of the adult insects are always taken into account in the way of describing a species or for taxonomic identification. Chorionic sculpturing of insect eggs has been accepted as a basis of ootaxonomy which is successfully analysed with the help of SEM (Hinton, 1981).
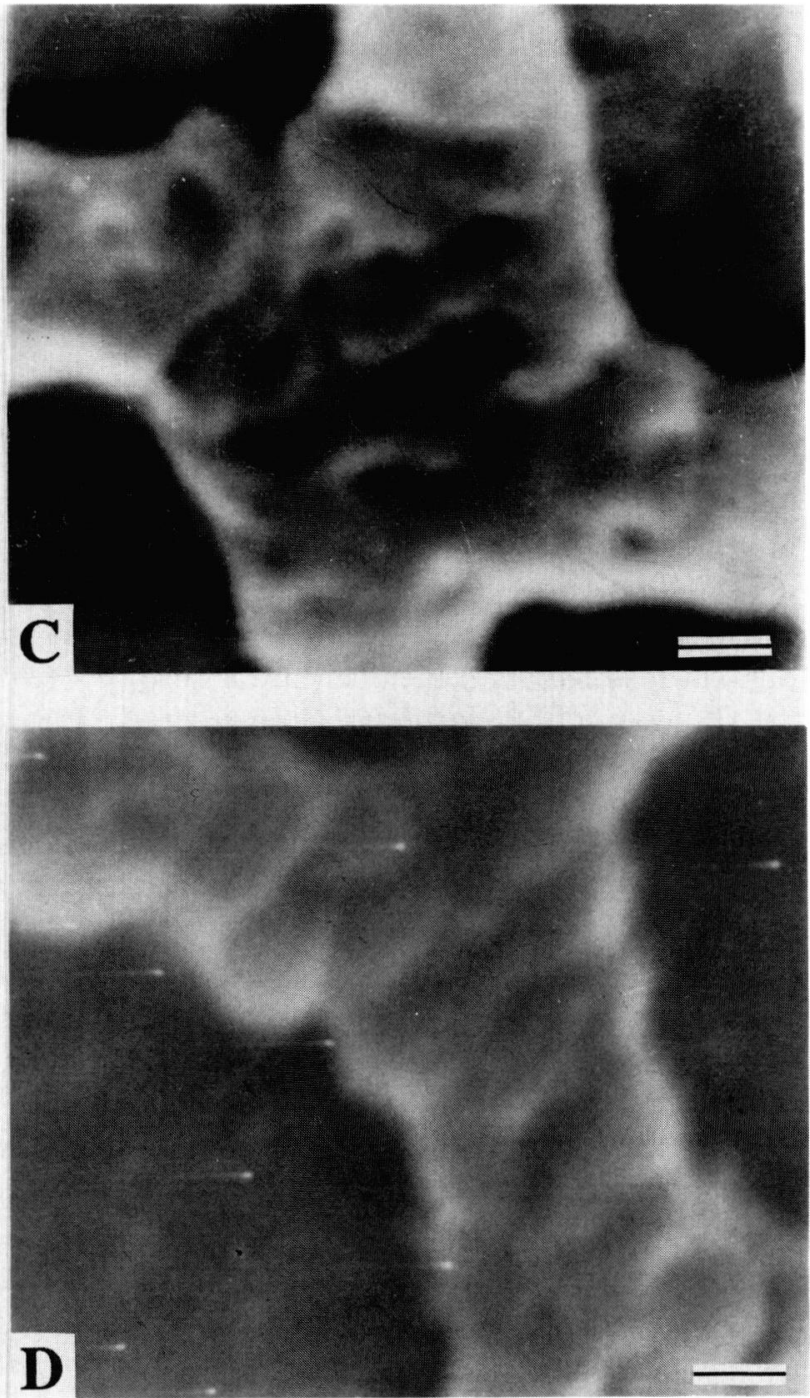

Fig. 3. - SEM micrographs showing the ridge morphology of the four Indian sandflies. P. argentipes (A); P. papatasi (B); P. m. major (C);S. zeylanica (D). $(\mathrm{Bar}=1 \mu \mathrm{m})$. 
From the result it is clear that the pattern of chorionic sculpturing has significant variation among the Indian phlebotomines. However, in the same genus or closely related species, the patterns are almost similar except the differences at the ultrastructural level. The chorionic sculpturing of $P$. argentipes eggs has been grouped under "connected parallel ridge". Although, $P$. papatasi egg falls under this category on the basis of distribution of ridges, there is a clear difference in the morphology of the ridges and the pattern by which they make interconnection and form some polygonal areas on the surface of the eggs. The two terminal ends of a $P$. papatasi egg are very diagnostic because the distribution of the ridges bears a very unique, diagnostic feature which is quite different from the rest of the egg surface (Fig. 2B).

In case of S. zeylanica, on the surface of the egg, the ridges form several, almost equal hexagonal areas but the pattern of formation of those hexagonal areas are quite different. The ridges never run in parallel and the six arms of the hexagons are almost of equal size unlike the hexagonal areas of Phlebotomus eggs, where two arms of the hexagon (in most cases which are parallel) are always longer than the other four arms (which are formed by small interconnecting ridges). In Sergentomyia group, the hexagonal areas are distributed throughout the egg surface whereas in case of Phlebotomus they are very scanty.

The sculpturing pattern of parallel connected ridges, observed in $P$. argentipes and $P$. papatas $i$ in this present investigation has also been reported in $P$. perniciosus by Fausto et al. (1992) and in Lutzomyia cruciata and Lu. anthophora by Endris et al. (1987). The other type of parallel ridges i.e., not transversely connected (or in other word, unconnected) has been found in P. langeroni (Lane \& El-Sawaf, 1986), P. martini (Kenya) and S. garnhami (Irungu et al., 1986). However, P. martini from Ethiopia showed different type of sculpturing pattern i.e., network type (GebreMichael \& Lane, 1991). This unconnected parallel ridge pattern has also been reported in P. perfiliewi (Fausto et al., 1992) and in Lu. diabolica (Endris et al., 1987) The polygon sculpturing pattern as observed here in case of P. m. major and S. zeylanica is most common in New World sandflies. Zimmerman et al. (1977), Endris et al. (1987) and Feliciangeli et al. (1993) described polygon sculpturing pattern in four, two and six New World sandflies out of six, five and eight species studied by them respectively.

From the present investigation it appears that parallel ridge formation is the basic pattern in $P$. argentipes (subgenus Pblebotomus Rondani \& Berté) and P. papatasi (subgenus Euphlebotomus) whereas in case of S. zeylanica (subgenus Neophlebotomus) and P. m. major (subgenus Larroussius), the basic pattern is polygonal. However, the finer differences between the eggs of $P$. argentipes and $P$. papatasi may be due to the microhabitat they use for their breeding and also for the structure of the follicular cells in the ovariole which is the manifestation of the character of the adult. Ward \& Ready (1975) stated that the form of sculpturing is believed to be influenced by environmental conditions of the breeding places. They also noted that, in the species of the genus Psychodopygus, there were some differences in the chorionic sculpturing although they are most abundant in the forest (Ward \& Killick-Kendrick, 1974). They indicated that the differences in microhabitat might be the cause behind the chorionic sculpturing variations among them. However, the chorionic sculpturing of Indian sandflies has been least studied and more informations are needed on the chorionic sculpturing of other Indian sandflies to have a better understanding on the relation of ecological habitat and the sculpturing pattern. However, it will be interesting to see whether genetic similarities or breeding habitat or a combination of both have some role in determining the chorionic sculpturing pattern of a species which, in turn, may provide the possible relationship among chorionic sculpturing, breeding habitat and genetics of phlebotomine sandflies. This might also help to have a solid understanding on sandfly taxonomy on the basis of chorionic topography.

\section{ACKNOWLEDGEMENTS}

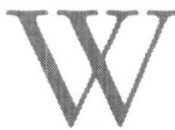
e are grateful to the Scanning Electron Microscope Unit, Regional Sophisticated Instrumentation Centre (RSIC), Bose Institute, Calcutta for providing SEM facility. The authors are thankful to Dr. François Palluault \& Dr. Martine Armstrong, Yale University for their help in translating the title, summary and key words into French.

\section{REFERENCES}

ABOnNEnC E. Les phlébotomes de la Région éthiopienne (Diptera: Psychodidae). Memoires ORSTOM, 1972, 55, 1-299.

ADDis C.T. Phlebotomus (Dampfomyia) anthophorus n. sp. and Pblebotomus diabolicus Hall from Texas (Diptera: Psychodidae). Journal of Parasitology, 1945, 31, 119-127.

BARRETTO M.P. Morphologia dos ovos, das larvas e das pupas de alguns Flebotomus de Sao Paulo. Anais da Faculdade de Medicina da Universidade de Sao Paulo, 1941, 17, 357-427.

Chaniotis B.N. \& ANDERSOn J.R. Notes on the morphology and laboratory rearing of Phlebotomus vexator occidentalis (Diptera: Psychodidae). Mosquito News, 1964, 42, 400-407. 
EMDEN F.I.V. The taxonomic significance of the characters of immature insects. Annual Review of Entomology, 1957, 2, 91-106.

Endris R.G., Young D.G. \& Perkins P.V. Ultrastructural comparison of egg surface morphology of five Lutzomyia species (Diptera: Psychodidae). Journal of Medical Entomology, 1987, 24, 243-247.

Fausto A.M., Maroli M., Mazzini M. Ootaxonomy investigation of three sandfly species (Diptera : Psychodidae) from Italy. Parassitologia, 1991, 33 (suppl. 1), 225-228.

Fausto A.M., Maroli M. \& Mazzini M. Ootaxonomy and the egg shell ultrastructure of Phlebotomus sandflies. Medical and Veterinary Entomology, 1992, 6, 201-208

Feliciangeli M.D., Castejon O.C. \& Limongi J. Egg surface ultrastrucure of eight New World phlebotomine sandfly species (Diptera: Psychodidae). Journal of Medical Entomology, 1993, 30, 651-656.

Gebre-Michael T. \& Lane R.P. Scanning electron microscopy of eggs of Phlebotomus (Synphlebotomus) martini and P. celiae (Diptera: Phlebotominae). Parassitologia, 1991, 33 (suppl. 1), 261-266.

GHOSH K.N. \& BhatTacharya A. Laboratory colonization of Phlebotomus argentipes (Diptera: Psychodidae). Insect Science and its Application, 1989, 10, 551-555.

Ghosh K.N., Ghosh D.K. De A. \& Bhattacharya A. Biology of Pblebotomus argentipes Annandale \& Brunetti and $P$. papatasi (Scopoli) in the laboratory. Annales de Parasitologie Humaine et Comparée, 1992, 67, 55-61.

Hinton H.E. Observations of the biology and the taxonomy of the eggs of Anopheles mosquitoes. Bulletin of Entomological Research, 1968, 57, 495-508.

Hinton H.E. Biology of Insect Eggs. Vol I-III, Pergamon Press, Oxford.

Hinton H.E. \& SERvice M.W. The surface structure of aedine eggs as seen with the scanning electron microscope. Annals of Tropical Medicine and Parasitology, 1969, 63, 409-411.

Howlett F.J. Indian sandflies. Transactions of the Bombay Medical Congress, 1909, 3, 239-242.

Irungu L.W., Mutinga M.J. \& KoKward E.D. Chorionic sculpturing of eggs of some Kenyan phlebotomine sandflies. Insect Science and its Application, 1986, 7, 45-48.

Johnson P.T. Autogeny in Panamanian Phlebotomus sandflies (Diptera: Psychodidae). Annals of the Entomological Society of America, 1961, 54, 116-116.

KILLICK-KEnDRICK R. Methods for the study of phlebotomine sandflies. In: The Leishmaniases in Biology and Medicine (Peters \& Killick-Kendrick eds), Academic Press, London, 1987, 473-497.

LEwIS D.J. The phlebotomine sandflies (Diptera: Psychodidae) of the Oriental Region. Bulletin of the British Museum (Natural History) Entomology Series, 1978, 37, 217-343.

LEwIS D.J. A taxonomic review of genus Phlebotomus (Diptera: Psychodidae). Bulletin of the British Museum (Natural History) Entomology Series, 1982, 45, 121-209.
LINDQUIST A.V. Notes on the habits and biology of a sandfly Phlebotomus diabolicus Hall, in Southern Texas (Diptera: Psychodidae). Proceedings of the Entomological Society of Washington, 1936, 38, 29-32.

Matsuo K., Yoshida Y. \& Lien J.C. The scanning electron microscopy of mosquitoes. I. The egg surface structure of 13 species of Aedes from Taiwan. Journal of Medical Entomology, 1974, 11, 179-188.

PERFIL'Ev P.P. Fauna of the USSR. Diptera: Phlebotomidae (sandflies). 1966, Vol. 3, No. 2, 382 p. (English translation, Jerusalem, 362 p., 1968).

SACCÀ G. Studi preimaginali di Pblebotomus perfiliewi Parrot, P. papatasi Scopoli, P. perniciosus Newstead (Diptera: Psychodidae). Rendiconti dell'Istituto Superiore di Sanita, 1950, 13, 680-688.

SACCÀ G. Descrizione dell'uovo e degli stadi larvali di Pblebotomus (Prophlebotomus) minus Rondani (Diptera, Psychodidae). Rendiconti dell'Istituto Superiore di Sanita, 1952, 15, 381-394.

SHERLOCK I. Sobre o Phlebotomus lenti Mangabeira, 1938 (Diptera: Psychodidae). Revista Brasileira de Biologia, 1957, 17, 77-88.

Sherlock I. \& Caneiro M. Descricao das fases imaturas do Phlebotomus babiensis Mangabeira \& Sherlock, 1961 (Diptera: Psychodidae). Memorias do Instituto Oswaldo Cruz, 1963, 61, 491-494.

Theodor O. Classification of the Old World species of the subfamily Phlebotominae. Bulletin of Entomological Research, 1948, 39, 85-111.

Troulletet J. Sergentomyia (Sergentomyia) bedfordi firmatus Parrot et Malbrant, 1945 et Sergentomyia (Sergentomyia) bedfordi medius Kirk et Lewis, 1950 (Diptera, Phlebotomidae). Étude morphologique des stades pré-imaginaux et notes bioécologiques. Annales de Parasitologie Humaine et Comparée, 1977, 52, 35-52.

Troullet J. Sergentomyia (Rondanomyia) ingrami Newstead, 1914, Sergentomyia (Rondanomyia) dureni Parrot, et Sergentomyia hamoni Abonnenc, 1958 (Diptera, Phlebotomidae). Etude morphologique des stades pré-imaginaux et notes bio-écologiques. Annales de Parasitologie bumaine et Comparée, 1979, 54, 353-373.

Ward R.D. \& KILLICK-KendRICK R. Field and laboratory observations on Psychodopygus lainsoni Fraiha and Ward and other sandflies (Diptera: Phlebotomidae) from the Transamazonian highway, Para State, Brazil. Bulletin of Entomological Research, 1975, 64, 213-221.

WARD R.D. \& Ready P.D. Chorionic sculpturing in some sandfly eggs (Diptera: Psychodidae). Journal of Entomo$\log y$ (Series A), 1975, 50, 127-134.

Zimmerman J.H., Newson N.D., Hooper G.R. \& ChrisTENSEN H.A. A comparison of the egg surface structure of six anthropophilic phlebotomine sandflies (Lutzomyia) with the scanning electron microscope (Diptera: Psychodidae). Journal of Medical Entomology, 1977, 13, 574-579.

Reçu le 16 juin 1995 Accepté le 20 septembre 1995 